\title{
PERANAN BIMBINGAN KONSELING ISLAM DALAM MENINGKATKAN MORAL NARAPIDANA ANAK: Studi pada BAPAS Kelas I Semarang
}

\author{
Safa' ${ }^{1}{ }^{1}$, Yuli Nur Khasanah ${ }^{2}$, Anila Umriana ${ }^{3}$ \\ ${ }^{1}$ MA Nurul Ulum Mranggen, ${ }^{2}$ Ponpes Ngruki Surakarta, \\ ${ }^{3}$ Universitas Islam Negeri (UIN) Walisongo Semarang \\ e-mail: syafa20fafa@gmail.com; yuli_nurhasanah@rocketmail.com; \\ anila.umriana@yahoo.com
}

\begin{abstract}
Abstrak
This paper describes the role of Islamic guidance and counseling to improve the morality of kid prisoners in the Probation and Parole Office (BAPAS) Class I Semarang. Initially, kid prisoners have low morals. However, having conducted Islamic guidance and counseling, the moral increased to be better. It was proven that Islamic guidance and counseling could help the kid prisoners restoring their spiritual mental and optimism in changing their behavior for the better moral quality. In addition, Islamic guidance and counseling has an important role to improve the kid prisoners' moral in the Probation and Parole Office (BAPAS) Class I Semarang. Its activities are particularly focused on the consciousness reversion through the faith strength, confidence, acceptance, and patience. Furthermore, patience and gentleness of the mentors make the kid prisoners have more spirit and confidence to participate in the process of Islamic guidance and counseling activities.
\end{abstract}

Tulisan ini mendiskripsikan tentang peranan bimbingan dan konseling Islam dalam meningkatkan moralitas narapidana anak di BAPAS Kelas I Semarang. Pada awalnya narapidana anak memiliki moral yang rendah, tetapi setelah dilakukan kegiatan BKI moral menjadi meningkat. Bimbingan Konseling Islam membantu narapidana anak mengembalikan mental spiritual, dan sikap optimisme dalam merubah perilaku mereka menjadi lebih baik, sehingga tercipta moral yang berkualitas. Bimbingan dan konseling Islam memiliki peran penting dalam meningkatkan moral narapidana anak di BAPAS Kelas I Semarang terutama merubah perilaku ke arah yang lebih baik dari sebelumnya. Kegiatan bimbingan konseling Islam lebih dikhususkan pada pengambilan kesadaran melalui kekuatan iman, keyakinan, penerimaan, dan kesabaran. Kesabaran dan kelembutan pembimbing menjadikan 
narapidana anak semakin semangat dan percaya diri dalam mengikuti proses bimbingan dan konseling Islam.

Kata Kunci: bimbingan konseling Islam; narapidana anak; BAPAS Kelas I Semarang

\section{A. Pendahuluan}

Moralitas menjadi hal penting dalam kehidupan. Moralitas merupakan kaidah norma yang mengatur perilaku individu dalam hubungannya dengan masyarakat dan kelompok sosial, sehingga bertujuan untuk mengukur standar baik dan buruk yang ditentukan oleh individu dengan nilai-nilai sosial budaya di mana individu tinggal. ${ }^{1}$ Moral berkembang sesuai dengan pengalaman individu yang menyangkut dua dimensi yaitu dimensi interpersonal dan dimensi intrapersonal. Dimensi intrapersonal meliputi pemikiran, persepsi, dan latar belakang kehidupan setiap individu, sedangkan lingkungan, teman sebaya, dan budaya merupakan dimensi interpersonal. Kedua dimensi tersebut berperan aktif pada setiap individu dan akan menentukan arah terhadap moral. ${ }^{2}$ Moralitas seseorang tumbuh melalui proses interaksi dengan pengalamannya, moral akan baik bila diajarkan dengan baik, begitu sebaliknya. Problem moral dihadapi semua generasi, dari anak, generasi muda, dewasa, hingga generasi tua. Problem moralitas anak, saat ini sedang menjadi perhatian banyak pihak. Hal ini dikarenakan, anak merupakan generasi tunas bangsa, yang akan menghantarkan menjadi Negara berperadaban tinggi, menjadi Negara hebat dan kuat karena moralitas anak-anak cenderung kuat dan baik.

Namun kenyataan yang terjadi, problem moralitas anak semakin memprihatinkan. Komisi Nasional (Komnas) Anak mencatat adanya peningkatan kasus kriminalitas yang dilakukan oleh anak. Tahun 2013 terdapat 730 kasus yang melibatkan anak sebagai pelaku kriminal anak, dan sebanyak 16\% pelaku kriminalitas berusia di bawah 14 tahun. Angka tersebut meningkat pada tahun 2014 menjadi 1.851 kasus atau meningkat sebanyak $26 \%{ }^{3}$ Hal tersebut karena

${ }^{1}$ Syamsul Bachri Thalib, Psikologi Pendidikan Berbasis Analisis Empiris Aplikatif, (Jakarta: Prenada Media Group, 2010), h. 57.

${ }^{2}$ Ahmad B. Barjie, Moralitas Generasi Muda dan Pendekatan Agama dalam Upaya Pembinaannya, (Jakarta: Proyek Pembinaan Kemahasiswaan Departemen Agama, 1987), h. 58.

${ }^{3} \mathrm{http}: / / \mathrm{m}$.gresnews.com/berita/sosial/2014 kasus kriminalitas anak diakses 26 Desember 2015 pukul 21.00 . 
kuatnya pengaruh lingkungan dan media yang banyak memberikan dampak negatif. Kondisi ini menunjukkan rendahnya moralitas anak.

Hasan menjelaskan bahwa perkembangan moral yang buruk akan berdampak pada kepribadian seseorang seperti; berbohong, mencuri, tindakan kriminal atau merusak, dan lain sebagainya. ${ }^{4}$ Anak-anak dengan moral buruk biasanya memiliki masalah dengan hukum, baik bersifat ringan, maupun berat. Anak dengan moralitas buruk dengan kasus hukum ringan mendapatkan perlakuan dan penanganan yang berbeda dengan anak dengan kasus moral hukuman tinggi. Kasus pencurian, pemalakan, tawuran meupakan kasus relatif ringan. Sedangkan kasus pembunuhan, perampasan, dan perampokan, merupakan kasus hukum berat.

BAPAS Kelas I Semarang merupakan suatu lembaga Pemasyarakatan yang menangani anak yang bermasalah (selanjutnya disebut narapidana anak). BAPAS Kelas I Semarang menjadi lembaga yang memiliki konsen untuk meningkatkan moral narapidana anak. ${ }^{5}$ Kasus paling banyak ditangani BAPAS adalah pencurian dan pengeroyokan, pergaulan bebas, penyalahgunaan narkotika, lakalantas, pembunuhan, dan perkelahian yang menyebabkan kematian. ${ }^{6}$ Untuk menangani problem moral narapidana anak memerlukan strategi penanganan khusus dan pendampingan intensif. Salah stunya dengan menerapkan bimbingan konseling Islam yang sesuai dengan kebutuhan perkembangan narapidana anak. Sebagaimana hakikat tujuan diselenggarakannya bimbingan konseling Islam adalah adanya perubahan sikap dan perilaku. ${ }^{7}$ Pelaksanaan bimbingan konseling Islam di BAPAS berorientasi pada perubahan sikap dan perilaku sebagai seorang anak yang berakhlak mulia. Mendasarkan hal tersebut penulis berupaya untuk mendeskripsikan dan menganalisis peranan bimbinngan konseling Islam dalam menangani kasus moral narapidana anak, menjadi bermoral baik.

${ }^{4}$ Aliah B. Purwakania Hasan, Psikologi Perkembangan Islami: Menyingkap tentang Rentang Kehidupan Manusia dari Prakelahiran hingga Kematian, (Jakarta: PT. Raja Grafindo Persada, 2006), h. 263.

${ }^{5}$ Wawancara dengan Ka. Sie.Bimbingan Narapidana Anak Bapas Kelas I Semarang, tanggal 16 Oktober 2016.

${ }^{6}$ Ibid.

${ }^{7}$ Anas Salahudin, Bimbingan dan Konseling, (Bandung: Pustaka Setia, 2010), h. 25. 
Tulisan ini menggunakan metode kualitatif, jenis field research. Sumber data primer adalah pembimbing atau konselor Islam (KI), pembimbing kemasyarakatan (PK), dan narapidana anak BAPAS Kelas I Semarang. Sumber data sekunder berasal dari buku-buku, jurnal, hasil penelitian sebelumnya, catatan notulen bapas yang berkaitan dengan moral narapidana anak dan pengurus di BAPAS Kelas I Semarang. Teknik pengumpulan data menggunakan observasi, wawancara, dan dokumentasi. ${ }^{8}$ Teknik analisis data menggunakan deskriptif kualitatif mengikuti model Milles dan Huberman. ${ }^{9}$

\section{B. Moral Anak}

Moral mengacu konsep tentang baik atau buruk yang disepakati dan menjadi komitme masyarakatan. Ada tatanan moral yang sifatnya individual, ada pula tatanan moral yang sifatnya sosial. Moral yang sifatnya individual merujuk pada komitmen tentang hal baik menurut ukuran pribadi, misalnya kejujuran, kemurahan hati, loyalitas, keterbukaan, kebaikan merujuk pada nilainilai yang telah disepakati sebagai suatu kebaikan. Moral yang sifatnya sosial dalam konteks kehidupan masyarakat, baik itu dalam konteks budaya, bernegara, kepercayaan dan kehidupan beragama, ternyata belum tentu disepakati sebagai hal yang baik oleh komunitas lainnya. ${ }^{10}$

Kata moral berasal dari bahasa Latin yaitu mores, yang berarti tata cara dalam kehidupan, adat istiadat dan kebiasaan. ${ }^{11}$ Kata moralitas dari bahasa Inggris adalah morality yang artinya sopan santun atau adat kesopanan. Menurut Thalib moral merupakan kaidah norma yang mengatur perilaku individu dalam hubungannya dengan masyarakat dan kelompok sosial, sehingga bertujuan untuk mengukur standar baik dan buruk yang ditentukan oleh individu dengan nilai-nilai sosial budaya di mana individu tinggal. ${ }^{12}$ Pelanggaran yang dilakukan pada tatanan nilai kesopanan dinamakan dekadensi moral atau tindakan

${ }^{8}$ Husaini Usman dan Akbar Purnomo Setyadi, Metodologi Penelitian Sosial, (Jakarta: Bumi Aksara, 2000), h. 73.

9Sugiyono, Metode Penelitian Pendidikan Pendekatan Kuantitatif, Kualitatif, dan RED, (Bandung: Alfabeta, 2010), h. 335-337.

${ }^{10}$ I Nyoman Surna, dkk, Psikologi Pendidikan, (Jakarta: Erlangga, 2014), h. 113.

${ }^{11}$ Singgih Gunarsa, Konseling dan Psikoterapi, (Jakarta: Gunung Mulia, 1992), h. 38.

${ }^{12}$ Syamsul Bachri Thalib, Psikologi Pendidikan Berbasis Analisis Empiris Aplikatif,(Jakarta: Prenada Media Group, 2010), h. 57. 
amoral. ${ }^{13}$ Moral merupakan kesadaran mental dan spiritual yang menimbulkan refleksi terhadap perbuatan, mencerminkan kesadaran, sehingga mampu membuat perisai atau benteng bagi kehidupannya menuju pada kualitas diri dalam moralnya. Dapat disimpulkan moral adalah penilaian terhadap kepribadian seseorang yang dinilai dari beberapa aspek, yaitu moral yang baik dan yang buruk berkenaan dengan kesopanan atau akhlak.

Perkembangan moral menurut Hurlock mempunyai aspek kecerdasan dan aspek impulsif. ${ }^{14}$ Aspek kecerdasan meliputi bagaimana seseornag harus mampu membedakan mana benar dan mana salah, mana baik, dan mana yang buruk dan memiliki penjelasan mengapa benar dan salah. Moral dalam aspek impulsif berkaitan dengan respond an sikap dalam mengembangkan keinginan dan melakukan hal yang benar, bertindak untuk kebaikan bersama, serta menghindari yang salah.

\section{Aspek Moral}

Terdapat tiga aspek dalam moral, yaitu afektif/ emosional, aspek kognitif, aspek perilaku. Aspek afektif/emosional moral (moral affect) merupakan berbagai jenis perasaan yang menyertai pelaksanaan prinsip etika. Islam mengajarkan pentingnya rasa malu untuk melakukan perbuatan yang tidak baik sebagai sesuatu yang penting. Dalam sebuah kitab hadis Syarah Riyadhush Shalihin, Abu Usamah Salim bin 'Ied al-Hilali dinyatakan:

$$
\begin{aligned}
& \text { عن ابي عمر رضي الله عنهما: ان رسول الله صلى الله عليه و سلم مر على } \\
& \text { رجل من الانصار و هويعظ اخاه فى الحياء, فقال رسول الله عليه وسلم: دعه الهي }
\end{aligned}
$$

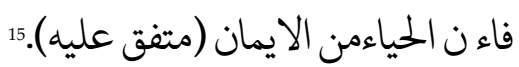

Dari Ibnu Umar, bahwa Rasulullah pernah berjalan melewati seseorang dari kaum anshar, yang pada saat itu dia tengah memberi nasihat kepada saudaranya yang pemalu. Maka Rasulullah bersabda: "Biarkan

\footnotetext{
${ }^{13}$ Ahmad B. Barjie, Moralitas Generasi Muda dan Pendekatan Agama ...., h. 8.

${ }^{14}$ Elizabeth B. Hurlock, Perkembangan Anak, (Jakarta: Penerbit Erlangga1989), h. 75.

${ }^{15}$ Syaikh Salim bin 'Ted al-Hilali, Syarah Riyadhus Shalihin, Jakarta: Pustaka Imam Syafi'i,
} 2015), h. 10. 
saja dia, karena sesungguhnya malu itu sebagian dari iman." (Muttafaq 'alaih).

Kedua, aspek kognitif moral (moral reasoning) merupakan pikiran yang ditunjukkan seseorang ketika memutuskan berbagai tindakan yang benar atau salah. Islam mengajarkan bahwa Allah mengilhamkan ke dalam jiwa manusia dua jalan yaitu jalan kefasikan dan ketakwaan. Manusia mempunyai akal untuk memilih jalan mana yang akan ditempuh seperti dalam al-Qur'an surah alSyams ayat 7-10:

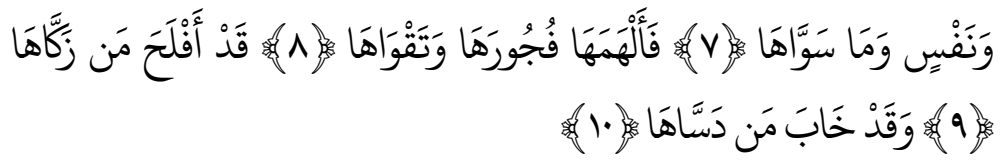

Dan jiwa serta penyempurnaan (ciptaan)-Nya, maka Allah mengilhamkan kepada jiwa itu (jalan) kefasikan dan ketakwaannya. Sesungguhnya beruntunglah orang yang menyucikan jiwa itu dan merugilah orang yang mengotorinya (QS. al-Syams [91]: 7-10). ${ }^{16}$

Ketiga, aspek perilaku moral (moral behavior) merupakan tindakan yang konsisten terhadap tindakan moral seseorang dalam situasi di mana mereka harus melanggarnya. Islam menggambarkan bahwa memilih melakukan jalan yang benar seperti menempuh jalan yang mendaki lagi sukar seperti dalam alQur'an surah al-Balad ayat 10-11:

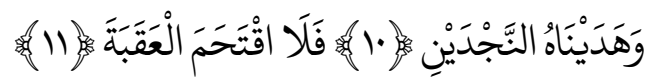

"Dan kami telah menunjukkan kepadanya dua jalan. Tetapi dia tidak menempuh jalan yang mendaki lagi sukar." (QS. al-Balad [90]: 10-11) ${ }^{17}$

\section{Faktor-faktor yang Mempengaruhi Moral}

Perkembangan moral seseorang dipengaruhi dari lingkungan tempat tinggal. Masa anak akan memperoleh nilai-nilai moral dari lingkungan di tempat mereka tinggal, anak memperoleh nilai-nilai dan perilaku sesuai dengan nilai yang diperoleh dari lingkungan sekitar, baik orang tua, teman, maupun masya-

${ }^{16}$ Departemen Agama RI, al-Qur'an dan Terjemahannya, (Bandung: al-Jumanatul 'Ali, 2004), h. 595.

${ }^{17}$ Ibid., h. 594. 
rakat. Peran orang tua dalam pembentukan moral anak sangat penting. Peran itu diunjukkan dalam bentuk pendampingan, pembentukan dan pembimbingan. ${ }^{18}$ Faktor yang mempengaruhi perkembangan moral adalah lingkungan sosial, perkembangan kognitif, empati, dan konflik kognitif. Variabel-variabel yang mempengaruhi perkembangan moral, termasuk perbedaan latar budaya, pengasuhan, keadaan sosial ekonomi, dan latar pendidikan orang tua, media. ${ }^{19}$

Menurut hasan terdapat tiga tahapan perkembangan moral yaitu prakonvensional, moralitas konvensional, dan pasca konvensional. Tingkat prakonvensional (preconventional stages), rentang usia 6-12 tahun tahap ini terdiri dari dua tahap yaitu hukuman dan kepatuhan (punishment and obedience) dan pertukaran instrumental. Tahap hukuman dan kepatuhan berisi penilaian tentang baik dan buruk tergantung pada konsekuensi fisik. Anak mematuhi tokoh otoritas untuk menghindari hukuman, dan tidak menganggap sesuatu merupakan kesalahan jika tidak diketahui dan tidak dihukum. Semakin berat kesalahan yang dilakukan, semakin berat hukuman yang diberikan. Belum terdapat pengenalan terhadap titik sudut orang lain yang mungkin berbeda dari yang lain. Tahap pertukaran instrumental (Instrumental Exchange). Pertukaran instrumental memungkinkan seseorang mematuhi aturan untuk mendapatkan penghargaan atau memenuhi tujuan pribadi. Telah terdapat kemampuan untuk melihat sesuatu dari perspektif lain, tetapi masih dilandasi keinginan untuk mendapatkan keuntungan. ${ }^{20}$

Tingkat moralitas konvensional (conventional morality), terjadi pada rentang usia 12-18 tahun. Pada tahap ini seseorang melakukan penalaran berdasarkan pandangan dan pengharapan kelompok sosial mereka. Aturan dan norma sosial dipatuhi untuk mendapatkan persetujuan orang lain atau untuk memelihara aturan sosial. Penghargaan dan penolakan sosial mengganti penghargaan atau hukuman yang konkret sebagai motivator perilaku etik. Perspektif orang lain telah dihargai dan dipertimbangkan dengan hati-hati. Ada dua tahap moralitas konvensional yaitu konformitas interpersonal (interpersonal conformity) dan mem-

${ }^{18}$ Anis Fitriyah, dkk, "Pengaruh Bimbingan Konseling Islam terhadap Peningkatan Moral Anak Jalanan di Sanggar Alang-Alang", Jurnal Bimbingan dan Konseling Islam, 3 (1), 2013, h. 102.

${ }^{19}$ Syamsul Bachri Thalib, Psikologi Pendidikan, h. 41.

${ }^{20}$ Aliah B. Purwakania Hasan, Psikologi Perkembangan Islami ..., h. 273. 
pertahankan aturan sosial (social order maintaining). Konformitas interpersonal merupakan tahap perilaku moral merupakan sesuatu yang menyenangkan, membantu atau disetujui orang lain. Perilaku dinilai dari niat pelakunya. Konsep seperti kesetiaan, kepercayaan dan rasa terima kasih mulai dikenal. Mereka mulai mengisi peran sosial diharapkan masyarakatnya. Sesuatu dikatakan benar jika memenuhi harapan masyarakat dan dikatakan buruk jika melanggar aturan sosial. Hukuman dilakukan untuk menghalangi terjadinya perbuatan buruk. Pada tahap hukum dan aturan (law and order), seseorang dapat melihat sistem sosial secara keseluruhan. Aturan dalam masyarakat merupakan dasar baik atau buruk, melaksanakan kewajiban dan memperhatikan penghargaan terhadap otoritas adalah hal yang penting. Alasan mematuhi peraturan bukan merupakan ketakutan terhadap hukuman atau kebutuhan individu, melainkan kepercayaan bahwa hukum dan aturan harus dipatuhi untuk mempertahankan tatanan fungsi sosial. $^{21}$

Tingkat pascakonvensional, terjadi pada rentang usia 18 tahun ke atas merupakan tahap perkembangan moral yang aturan-aturan dan ungkapanungkapan moral dirumuskan secara jelas berdasarkan nilai-nilai dan prinsip moral yang memiliki keabsahan dan dapat diterapkan. Tingkatan ini terlepas dari otoritas kelompok atau orang yang berpegangan pada prinsip tersebut, dan terlepas pula dari identifikasi diri dengan kelompok tersebut. Terdapat dua tahap, pasca konvensional yaitu orientasi kontrak sosial legalitas dan prinsip etika universal. Tahap orientasi kontrak sosial legalitas orang memilih prinsip moral untuk hidup, dan tahap prinsip etika universal berarti orang bertingkah laku dengan cara menghormati harga diri semua orang.

\section{Moral Narapidana Anak di BAPAS Kelas 1 Semarang}

Berdasarkan data di BAPAS Kelas I Semarang sampai bulan Mei 2016 terdapat 216 narapidana anak, diantaranya yaitu: pencurian sebanyak 150 kasus, pengeroyokan 25 kasus, pencabulan 18 kasus, narkoba 11 (sebelas) kasus, penggelapan 7 (tujuh) kasus, pornografi 3 (tiga) kasus, dan pembunuhan 3 (tiga) kasus. Pencurian merupakan kasus terbanyak. Kasus pencurian dilakukan oleh anak di bawah umur 18 tahun. ${ }^{22}$ Dari 150 kasus pencurian, BAPAS Kelas I

\footnotetext{
${ }^{21}$ Aliah B. Purwakania Hasan, Psikologi Perkembangan Islami ..., h. 274.

${ }^{22}$ Wawancara dengan Putri, tanggal 21 Mei 2016.
} 
Semarang menanngani kasus sebanyak 10 (sepuluh) anak. Moral dari 10 (sepuluh) anak tersebut secara umum masuk dalam kategori sedang. BAPAS melakukan langkah untuk memudahkan pembinaan moral dengan memberi peringkat atau rangking. Narapidana anak yang sudah menunjukan sikap dan tindakan positif akan ditempatkan pada ringking pertama, sedangkan anak yang masih belum menunjukkan sikap dan tindakan positif ditempatkan pada ringking 10 (sepuluh).

Moral yang dimiliki oleh narapidana anak di BAPAS Kelas I Semarang berbeda-beda, ada yang sudah mengalami peningkatan moral yang lebih baik ada juga yang masih di bawah kualitas atau belum ada peningkatan yang signifikan. Moral narapidana anak BAPAS Kelas I Semarang dapat dilihat dalam tiga aspek yaitu afektif, kognitif, dan perilaku. Moral pada aspek afektif berupa tidak takut melakukan pencurian, suka berbohong, tidak takut melakukan pencurian, suka memukul temannya, mudah melukai orang lain, minum-minuman keras, membantah orang tua, hanya peduli dengan diri sendiri, dan berbohong sama orang tua, berbicara kasar pada orang tua, meninggalkan ibadah shalat dan ngaji. Moral aspek kognitif berupa pemahaman bahwa mencuri itu hal biasa dan tidak takut dosa, suka mencuri dan menyakiti teman, tidak/belum memiliki cita-cita yang jelas, dan mudah terbujuk oleh teman untuk melakukan hal negatif seperti menipu. Moral aspek perilaku ditunjukkan dalam bentuk masih mencuri, tidak peduli dengan perasaan orang lain dan tidak tahu shalat, proses belajar shalat dan mengaji, tidak/belum memiliki cita-cita yang jelas, sering nongkrong malam.

Penurunan moral narapidana anak BAPAS Kelas I Semarang terjadi karena beberapa faktor diantaranya kurangnya pengawasan dan kasih sayang orang tua, pergaulan dengan teman sebaya yang diluar batas, kondisi ekonomi keluarga yang minim, pola asuh orang tua yang salah, lingkungan masyarakat yang tidak baik. Rata-rata alasan anak melakukan tindakan kriminalitas karena keadaan terpaksa untuk bertahan hidup, untuk mendapatkan perhatian dari orang dewasa, dan tidak tau kalau perbuatan yang dilakukannya itu adalah tindakan melanggar hukum. Untuk itu anak-anak yang berhadapan dengan hukum perlu bimbingan dan konseling Islam guna membimbing mereka untuk kembali ke jalan yang benar dan sesuai dengan fitrahnya sebagai manusia. ${ }^{23}$

${ }^{23}$ Wawancara dengan Catur, tanggal 20 Mei 2016. 


\section{Bimbingan Konseling Islam dalam Meningkatkan Moral Narapidana Anak}

Bimbingan Konseling oleh BAPS Kelas 1 Kota Semarang dilakukan secara intensif, mulai dari bimbingan personal, kelompok, bimbingan mental, bimbingan spiritual, dan reintegrasi sosial. Bimbingan personal dilakukan saat narapidana anak belum memahami dan menyadari akibat dari tindakan yang dilakukan. Bimbingan konseling kelompok dilakukan dengan role play. Bimbingan mental dilakukan untuk menumbuhkan sikap mental positif bagi narapidana anak. Bimbingan spiritual diarahkan pada bimbingan keagamaan untuk melaksanakan ibadah dan mengingat Tuhannya. Reintegrasi sosial dilakukan kepada narapidana anak saat akan kembali ke lingkungan masyarakat.

Pelaksanaan bimbingan konseling Islam tidak bisa terlepas dari materi yang diberikan pada narapidana anak. Materi yang diberikan BAPAS Kelas I Semarang disesuaikan dengan tujuannya dan sesuai kebutuhan narapidana anak. Secara umum, materi yang diberikan dalam proses kegiatan bimbingan dan konseling Islam mencakup tiga aspek, yaitu; figh, al-Qur'an dan sosial agama Islam. ${ }^{24}$ Aspek Fiqh, difokuskan pada figh ibadah, khususnya kompetensi thaharah, shalat, puasa. Aspek al-Qur'an, difokuskan pada kompetensi membaca alQur'an bagaimana narapidana melakukan darus al-Qur'an setiap hari di rumah meskipun hanya satu halaman. Aspek sosial keagamaan, maksudnya yaitu narapidana diajari untuk mengikuti kegiatan-kegiatan sosial yang dikaitkan dengan agama, misalnya; membaca do'a-do'a, berdzikir, dan tolong menolong dalam kebaikan.

Pembimbing atau konselor tidak dapat menyampaikan materinya tanpa adanya metode. Metode yang digunakan dalam proses bimbingan dan konseling Islam di BAPAS Kelas I Semarang, yaitu dengan menggunakan metode teknik SEFT (Spiritual Emotional Frendoom Technique). Dalam menangani anak yang terlibat kasus kriminalitas pencurian perlu penanganan teknik khusus, yaitu menggunakan metode SEFT. ${ }^{25}$ SEFT adalah teknik penyembuhan yang memadukan keampuhan energi psikologi dengan kekuatan do'a dan spiritualitas.

\footnotetext{
${ }^{24}$ Wawancara Ustadz Anas, tanggal 22 Agustus 2016.

${ }^{25}$ Data observasi pendahuluan tanggal 22 Mei 2016.
} 
Energi psikologi adalah ilmu yang menerapkan berbagai prinsip dan teknik berdasarkan konsep sistem energi tubuh untuk memperbaiki kondisi pikiran, emosi dan perilaku seseorang. Metode terapi ini menggunakan metode tapping di titik titik kunci yang jumlahnya ada 18 titik tapping. Seft (spiritual emotional freedom technique) ini dikembangkan oleh Ahmad Faiz Zainuddin, lulusan psikologi Unair, dari terapi asalnya, EFT (emotional freedom technique) yang disederhanakan menjadi SEFT. Metode SEFT memiliki prinsip dalam menangani moral narapidana anak, anak tidak diposisikan sebagai orang yang selalu dipersalahkan, tetapi menempatkannya sebagai seseorang yang perlu dibantu. Terdapat tiga wilayah SEST yaitu sentuh kebutuhannya, sentuh emosinya, dan sentuh spiritualnya.

Bimbingan konseling Islam yang dilakukan BAPAS secara umum memiliki peran penting dalam meningkatkan moralitas narapidanan anak di kelas 1 Semarang. Peranan ini ditunjukkan dengan orientasi perubahan sikap para narapidana anak. Pada aspek materi yang didesain sesuai kebutuhan anak, berperan secara simultan untuk memberikan pemahaman dna kesadaran melakukan perbuatan atau perilaku. Bimbingan konseling islam yang dilakukan memberikan hasil penanganan yang cukup baik, dilihat dari hasil perubahan sikap yang positif pada narapidana anak. Meskipun dalam pelaksanaan terhambat oleh anggaran dari pemerintah pusat, BAPAS Kelas I Semarang dalam memenuhi hak narapidana anak mendapatkan bimbingan konseling Islam melibatkan stakeholders. BAPAS mengajak lembaga-lembaga yang mau membantu memberikan bimbingan konseling Islam untuk narapidana anak. Dan perlu adanya kesamaan persepsi diantara penegak hukum dan komitmen yang kuat dari para pimpinan dalam memberikan bimbingan konseling Islam bagi narapidana anak. Karena sebenarnya anak yang bertindak kriminalitas bukan dari kemauan hati mereka, akan tetapi mereka melakukan tindakan kriminalitas tidak sengaja dan karena keterpaksaan. Dalam hal ini sangat diperlukan pemberian bimbingan bagi anak-anak tindakan kriminalitas.

Peran seorang pembimbing menjadi kunci keberhasilan peningkatan moral anak, pebimbing tidak hanya sebagai orang yang memiliki afliasi untuk membantu memberikan arahan dan nasihat kepada anak, namun pembimbing berperan sebagai motivator, penasihat, pemberi suri tauladan yang baik. Pembimbing juga memberikan kerangka acuan dna pemikiran kepada narapidana 
anak untuk menjadi generasi yang membanggakan dan menguntungkan bagi negara. Berkaitan dengan peran metode, tentunya dengan penggunaan SEST, menjadikan anak merasa nyaman, lebih meresapi dan selanjutnya memiliki internalisasi nilai-nilai keislaman dalam setiap kehidupannya. Langkah yang ditempuh BAPAS tentu memberikan pemahaman kepada masyarakat dan negara bahwa narapidana anak membutuhkan dukungan dan bimbingan sehingga mereka memiliki kemampuan dan keberanian memunculkan moralitas baik dalam kehidupannya.

\section{E. Analisis Bimbingan Konseling Islam dalam Meningkatkan Moralitas Narapidana Anak}

Menurut adz-Dzaky bimbingan konseling Islam adalah suatu aktivitas memberikan bimbingan, pelajaran, dan pedoman kepada individu agar dapat mengembangkan potensi akal pikirannya, kepribadiannya, keimanannya, dan keyakinannya sehingga dapat menanggulangi problematika hidup dengan baik dan benar secara mandiri yang berpandangan pada al-Qur'an dan Sunnah Rasulullah. ${ }^{26}$ Peranan bimbingan konseling Islam dalam meningkatkan moral narapidana anak di BAPAS Kelas I Semarang dilakukan untuk memberikan pemahaman diri akan potensi yang diberikan kepada diri narapidana anak di BAPAS Kelas I Semarang dan sebagai bantuan yang ditujukan untuk pemecahan masalah yang menyangkut diri pribadi, individu maupun kelompok.

Peranan bimbingan konseling Islam di Bapas Kelas I Semarang guna untuk membantu proses penyembuhan dan pemulihan serta menuntun kearah yang lebih baik dan lebih dekat dengan Allah. Bimbingan dan konseling Islam kepada narapidana anak pelaku kriminalitas ditangani langsung oleh pembimbing Islam atau konselor Islam. Pembimbing memberikan bimbingan dengan menggunakan berbagai pendekatan dan penanaman akidah, akhlak, serta ibadah kepada narapidana anak melalui nasihat-nasihat atau kata-kata yang menyentuh hati mereka. Bimbingan dan konseling Islam di BAPAS Kelas I Semarang merupakan suatu upaya dalam membantu merubah perilaku menyimpang narapidana anak untuk menjadi pribadi yang bermoral, serta membantu memberikan

${ }^{26}$ Hamdani Bakran Adz-Dzaky, Psikoterapi dan Konseling Islam, (Yogyakarta: Fajar Pustaka, 2001), h. 137. 
pemulihan mental narapidana anak pelaku kriminalitas agar lebih tenang, ikhlas, sabar, dan tabah dalam menghadapi ujian yang dialaminya.

Isi materi bimbingan dan konseling Islam dan cara-cara yang digunakan menurut ajaran Islam dapat membantu para narapidana dalam menghadapi masalah yang berkaitan dengan kehidupannya. Terutama berhubungan dengan krisis kejiwaan, seperti pencarian konsep diri yang berhubungan dengan kepribadian, dan lainnya. Bimbingan dan konseling Islam sebagai suatu bantuan dari ahli sangat dibutuhkan bagi para narapidana yang bermasalah, agar mereka dapat berkesempatan membenahi diri mereka sendiri yang sedang dalam masa pubertas atau masa pencarian jati diri. Jika dibiarkan tidak terarah dan tanpa bimbingan dikhawatirkan akan menyebabkan berbagai bentuk masalah kenakalan remaja. Dengan bimbingan ajaran Islam berupa keimanan, keibadahan dan akhlak Islami, diharapkan narapidana akan mendapat pencerahan sehingga dapat menemukan konsep diri yang sejatinya akan mereka bawa terus kepada masa dewasanya kelak. Bimbingan dan konseling Islam yaitu bimbingan yang dilakukan melalui cara-cara yang berkaitan dengan dakwah Islam seperti ta'lim atau menuntut ilmu (pengkajian) yang di sebut dengan al-Irsyad, nashihah (nasihat yang baik), atau isytisyfa (pengobatan) penyakit-penyakit kejiwaan seperti kesombongan, keluh kesah, tidak bersyukur dan lain sebagainya, dengan bimbingan dari segi ilmu untuk kemudahan hidup dan dzikir untuk ketenangan jiwa serta metode bisa membantu narapidana memperbaharui atau menambah keimanan serta ketaqwaan kepada Allah sehingga hidup dapat dijalani dengan baik. $^{27}$

Peranan bimbingan konseling Islam dalam meningkatkan moral narapidana anak di BAPAS Kelas I Semarang dilakukan untuk memberikan pemahaman diri akan potensi yang diberikan kepada diri narapidana anak dan menumbuhkan kembali sikap optimisme narapidana anak BAPAS Kelas I Semarang untuk tidak mengulangi perilaku buruk yang telah mereka lakukan. Lebih dari itu melalui bimbingan dan konseling Islam ini juga membuat para narapidana anak bisa merasakan kepercayaan kepada dirinya dalam bermasyarakat. Peranan bimbingan konseling Islam dalam meningkatkan moral

${ }^{27}$ Ainur Rahim Faqih, Bimbingan dan Konseling dalam Islam, (Yogyakarta: UUI Press, 2001), h. 39 . 
narapidana anak di BAPAS Kelas I Semarang ini diutamakan untuk merubah perilaku narapidana anak menuju ke arah yang lebih baik dari sebelumnya. Bimbingan konseling Islam lebih dikhususkan kepada pengembalian kesadaran narapidana melalui kekuatan iman yang tertanam dalam jiwanya. Maka, pendampingan mutlak dibutuhkan, karena dalam diri narapidana menemui berbagai macam kesulitan berinteraksi dalam kaitannya menjalankan proses kehidupan bermasyarakat. Selain itu para narapidana anak terkadang masih mengalami kebimbangan dalam hati mereka dan mudah terbujuk oleh teman yang berperilaku negatif. Untuk itu diperlukan sebuah pendampingan yang membuat mereka bisa mengembalikan rasa percaya diri mereka khususnya dalam menjalani kehidupan menuju moral yang baik. Dengan bimbingan ini, para narapidana anak akan lebih mudah dalam mengontrol dirinya serta mampu memotivasi dirinya sendiri agar menjadi pribadi yang lebih mantap dan mandiri. Bimbingan konseling Islam ini juga berperan untuk memberikan pengarahan bagi para narapidana untuk memahami serta mengembangkan potensi yang mereka miliki seutuhnya. ${ }^{28}$

Menurut Adz-Dzaky29 bimbingan dan konseling Islam adalah suatu aktivitas memberikan bimbingan, pelajaran, dan pedoman kepada individu yang meminta bimbingan (narapidana) dalam hal bagaimana sehingga seorang narapidana dapat mengembangkan potensi akal pikirannya, kepribadiannya, keimanannya, dan keyakinannya sehingga dapat menanggulangi problematika hidup dengan baik dan benar secara mandiri yang berpandangan pada al-Qur'an dan Sunnah Rasulullah.

Melihat pentingnya bimbingan dan konseling Islam, maka penting diterapkan untuk orang yang bermasalah maupun yang tidak, karena pada dasarnya dengan adanya bimbingan dan konseling Islam orang akan selalu mengingat Allah, membantu sedikit demi sedikit beban hati, dengan berbagai pengarahan yang diberikan sehingga hidupnya akan lebih tenang dan terarah.

Menurut Yusuf dan Juntika menjelaskan bahwa dalam jangka pendek tujuan adanya bimbingan dan konseling Islam supaya individu dapat memahami

\footnotetext{
${ }^{28}$ Wawancara dengan Ustadz Anas tanggal 22 Juni 2016

${ }^{29}$ Hamdani Bakran adz-Dzaky, Psikoterapi dan Konseling Islam, h. 137.
} 
dan menaati tuntuan dalam al-Qur'an. ${ }^{30}$ Diharapkan individu dapat memiliki keimanan yang kuat, dan secara pelan-pelan mampu meningkatkan kualitas kepatuhan dan ketakwaannya kepada Allah. Untuk jangka panjang yang ingin dicapai adalah agar individu yang dibimbing secara bertahap bisa berkembang menjadi pribadi kaffah. BAPAS kelas 1 Semarang telah melaksanakan proses bimbingan yang diarahkan untuk melakukan perubahan pada narapidana. Kegiatan bimbingan konseling Islam direncanakan dengan menetapkan hal-hal berikut data narapidana, pembimbing, tujuan bimbingan, program kerja bimbingan, dan ketentuan-ketentuan dalam melaksanakan kegiatan bimbingan.

Bimbingan konseling Islam dalam meningkatkan moral narapidana anak berbeda dengan BAPAS lain. Perbedaan tersebut terletak pada pelaksanaan bimbingan yang dilakukan. Proses bimbingan terhadap narapidana anak dan pendekatan yang digunakan diupayakan agar tidak menyinggung narapidana. Untuk itu BAPAS Kelas 1 Semarang menetapkan tiga prinsip bimbingan, yaitu pendekatan secara persuasif, pemberian motivasi, dan perhatian secara khusus yang berkelanjutan. Tiga prinsip tersebut dilakukan secara simultan dalam melaksanakan bimbingan. Pertama, pendekatan secara persuasif dimaksudkan sebagai upaya bimbingan dengan cara membujuk secara halus dan penuh kasih sayang. Pendekatan ini sangat diperlukan agar tujuan bimbingan dapat diterima oleh para narapidana agar tidak mudah tersinggung. Rayuan dan bujukan secara halus, penuh kasih sayang oleh pembimbing diharapkan bisa mempengaruhi para narapidana untuk mengikuti kegiatan ataupun saran dari BAPASKelas 1 Semarang. Kedua, pemberian motivasi merupakan upaya bimbingan dengan cara memberikan dorongan agar narapidana anak bersemangat melakukan kegiatan-kegiatan ataupun saran yang diberikan oleh BAPASKelas 1 Semarang. Pemberian motivasi ini dilakukan pembimbing dalam berbagai kesempatan, baik secara formal maupun informal. Pemberian informasi secara formal biasanya dilakukan dalam kegiatan bimbingan kepribadian dengan metode ceramah. Sedangkan motivasi secara informal dilakukan pembimbing dalam bentuk ngobrol santai. Hal ini sangat baik karena bisa membina keakraban dan kedekatan antara pembimbing dengan narapidana yang dibimbing.

${ }^{30}$ Yusuf Syamsul dan Juntika Nurihsan, Landasan Bimbingan dan Konseling, (Bandung: Remaja Rosdakarya, 2005), h. 25. 
Ketiga, perhatian secara khusus dan berkelanjutan yang dimaksud adalah bimbingan dilakukan dengan memberikan pengawasan berdasarkan perilaku narapidana sebelum masuk BAPASkelas 1 Semarang. Narapidana anak harus mendapatkan perhatian secara khusus dari pembimbing. Perhatian tersebut tidak hanya dilakukan pada waktu-waktu tertentu, tetapi dilakukan secara berkelanjutan dan terus menerus.Materi yang diberikan kepada narapidana dalam rangka membimbing mereka agar lebih baik dari sebelumnya di fokuskan pada tiga aspek, yaitu aspek ibadah, aspek al-Qur'an dan aspek sosial keagamaan. Tiga aspek ini merupakan aspek dasar yang harus dimiliki oleh setiap manusia sebagai makhluk Tuhan dan sebagai makhluk sosial. Sebagai makhluk Tuhan manusia memiliki kewajiban beribadah dan berdakwah. Sedangkan sebagai makhluk sosial manusia harus mampu menjadi sumber kedamaian dan ketenangan bagi manusia yang lain.

\section{F. Kesimpulan}

Kondisi moral narapidana anak di BAPAS Kelas I Semarang dikatakan buruk jika dilihat dari aspek afektif, kognitif dan perilaku seperti tidak takut dosa, belum bisa membedakan mana yang baik dan mana yang buruk, mudah terpengaruh oleh pergaulan yang menyimpang. Sementara itu, jika moral narapidana anak dikatakan meningkat dilihat dari aspek afektif,kognitif dan perilaku moral seperti sudah berhenti mencuri karena takut dosa, bisa mencari jalan keluar dari permasalahannya sendiri, bisa meninggalkan pergaulan yang tidak baik. Peranan bimbingan dan konseling Islam di BAPAS Kelas I Semarang, secara perlahan dapat membantu narapidana anak mengembalikan mental spiritual, dan sikap optimisme dalam merubah perilaku mereka menjadi lebih baik, sehingga tercipta moral yang berkualitas. Peranan bimbingan dan konseling Islam dalam meningkatkan moral narapidana anak di BAPAS Kelas I Semarang ini diutamakan untuk merubah perilaku narapidana anak menuju ke arah yang lebih baik dari sebelumnya. Bimbingan dan konseling Islam lebih di khususkan kepada pengambilan kesadaran narapidana melalui kekuatan iman yang tertanam dalam hatinya.[] 


\section{Daftar Pustaka}

Barjie, Ahmad B., Moralitas Generasi Muda dan Pendekatan Agama dalam Upaya Pembinaannya, Jakarta: Proyek Pembinaan Kemahasiswaan Departemen Agama, 1987.

Data observasi pendahuluan tanggal 22 Mei 2016.

Departemen Agama RI, al-Qur'an dan Terjemahannya, Bandung: al-Jumanatul 'Ali, 2004.

adz-Dzaky, Hamdani Bakran, Psikoterapi dan Konseling Islam, Yogyakarta: Fajar Pustaka, 2001.

Faqih, Ainur Rahim, Bimbingan dan Konseling Dalam Islam, Yogyakarta: UUI Press, 2001.

Fitriyah, Anis, dkk, "Pengaruh Bimbingan Konseling Islam terhadap Peningkatan Moral Anak Jalanan di Sanggar Alang-Alang", Jumal Bimbingan dan Konseling Islam, 3 (1), 2013, h. 102.

Gunarsa, Singgih, Konseling dan Psikoterapi, Jakarta: Gunung Mulia, 1992.

Hasan, Aliah B. Purwakania, Psikologi Perkembangan Islami: Menyingkap tentang Rentang Kehidupan Manusia dari Prakelahiran hingga Kematian, Jakarta: Raja Grafindo Persada, 2006.

al-Hilali, Syaikh Salim bin 'Ied, Syarah Riyadhus Shalihin, Jakarta: Pustaka Imam Syafi'i, 2015.

http://m.gresnews.com/berita/sosial/2014 kasus kriminalitas anak diakses 26 Desember 2015 pukul 21.00.

Hurlock, Elizabeth B., Perkembangan Anak, Jakarta: Penerbit Erlangga 1989.

Salahudin, Anas, Bimbingan dan Konseling, Bandung: Pustaka Setia, 2010.

Sugiyono, Metode Penelitian Pendidikan Pendekatan Kuantitatif, Kualitatif, dan R\&D, Bandung: Alfabeta, 2010.

Surna, I Nyoman, dkk, Psikologi Pendidikan, Jakarta: Erlangga, 2014.

Syamsul, Yusuf dan Juntika Nurihsan, Landasan Bimbingan dan Konseling, Bandung: Remaja Rosdakarya, 2005. 
Thalib, Syamsul Bachri, Psikologi Pendidikan Berbasis Analisis Empiris Aplikatif,, Jakarta: Prenada Media Group, 2010.

Usman, Husaini dan Akbar Purnomo Setyadi, Metodologi Penelitian Sosial, Jakarta: Bumi Aksara, 2000.

Wawancara dengan Catur, tanggal 20 Mei 2016.

Wawancara dengan Ka. Sie.Bimbingan Narapidana Anak Bapas Kelas I Semarang, tanggal 16 Oktober 2016.

Wawancara dengan Putri, tanggal 21 Mei 2016.

Wawancara dengan Ustadz Anas tanggal 22 Juni 2016.

Wawancara Ustadz Anas, tanggal 22 Agustus 2016. 